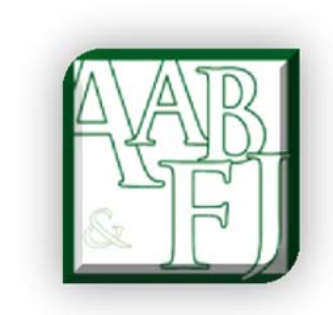

\title{
Implementing a Sustainability Balanced Scorecard to Contribute to the Process of Organisational Legitimacy Assessment
}

\author{
Tairan Huang, Matthew Pepper, Graham Bowrey ${ }^{1}$
}

\begin{abstract}
The purpose of this paper is to illustrate the use of a Sustainability Balanced Scorecard (SBSC) as a contributing factor in the process of organisational legitimacy assessment. The methodological approach in this study is supported by the application of content analysis to identify and examine the disclosed sustainability indicators of a major Australian financial institution (Westpac). The theoretical lens of legitimacy theory and the Balanced Scorecard (BSC) are used as points of reference to inform and structure the overall theoretical framework of this study. The results indicate that the four perspectives of a traditional BSC correlate with the main sources of influential inputs to Westpac's sustainability reporting. In addition, the SBSC presented in this article successfully illustrates focal areas of reporting practice, providing a succinct overview of an organisation's reporting activities. The primary contributions of this research are to the literature on social and environmental disclosures, including the research of Do, Tilt and Tilling (2007), and Baxter, Chua and Strong (2010) and the provision of a practical technique to illustrate the focal activity of an organisation's social and environmental reporting as part of the legitimisation process.
\end{abstract}

Keywords: Balanced Scorecard, legitimacy, sustainability

JEL Classification: M40

\footnotetext{
${ }^{1}$ University of Wollongong
} 


\section{Introduction}

Issues concerning sustainability have attained a high level of social awareness, with climate change, corporate social responsibilities and the impacts of corporate business activities frequently making media headlines. Modern corporations now face a newly-emerging business phenomenon, known as Sustainability Performance Management, which addresses the social, environmental and economic (performance) aspects of corporate management and corporate sustainability management (Schaltegger \& Wagner 2006).

Sustainability reporting is regarded as an attempt by many business organisations to account for the social and environmental impact of their operations. This accountability has become a central concern for businesses in modern society and many organisations now claim that they recognise the social and environmental impacts resulting from their economic activities (Unerman, Bebbington \& O’Dwyer 2007). Thus, it is important to identify the processes governing the development of an organisation's sustainability practices, as these will affect the approaches and methods used by organisations to account for and disclose their sustainability performance. Schaltegger and Wagner (2006) suggest that managing sustainability performance requires "a sound management framework which firstly links environmental and social management with the business and competitive strategy, and secondly, that integrates environmental and social information with economic business information and sustainability reporting” (p6).

Reporting social and environmental activities still remains largely voluntary for most businesses and organisations. In the absence of legislation, guidelines and initiatives have been developed and made available for organisations to demonstrate their social and environmental management and performance. Adams and Narayanan (2007) classified these

guidelines according to the differences in their reporting focus, and indicated that none of the guidelines address all organisations' perceived needs in relation to sustainability reporting. To a large extent, differences in organisations' perceptions of sustainability exist because sustainable activities vary according to context. In support of this, Hopwood (2009) posits that there are "different approaches to both conceiving and acting upon human and organisational interaction with the environment" (p433). Using this as a point of reference, this research aims to identify some of the strategies and mechanisms that a firm could use to develop context specific sustainability reporting systems to meet the information needs of their stakeholders. A SBSC is used for this purpose as both a visual reporting tool and classification technique. It has been adopted, in this case, as an inherent part of the legitimisation process.

\section{Research Motivation}

Westpac is one of the leading specialist financial services managers and distributors in Australia. In 2002, the company began issuing a stand-alone report on its sustainabilityrelated activities. Since then, Westpac has continued to expand its sustainability practices and now includes sustainability reporting as part of its organisational performance disclosure practice. Westpac's effort was recognised by the Dow Jones Sustainability Index (DJSI), which ranked Westpac as the most environmentally sustainable bank for the period 2002$2007^{2}$. This is significant because, since its launch in 1999, the DJSI has gained the reputation as the leading global sustainability benchmark which investors can use to assist them with green investment decisions (Hope \& Fowler, 2007). The DJSI incorporates a Triple Bottom Line (TBL) approach, analysing economic, environmental and social performance, and

\footnotetext{
${ }^{2}$ Shared with ANZ in 2007.
} 
demonstrates a positive risk/return profile for investors who choose to invest with DJSI-listed firms (Knoepfel 2001). Previous research (for example, Artiach et al. 2010; Baskin 2006; Ricart et al.2005) has used DJSI-listed firms to measure the relationship between sustainability management and value creation. The view that the integration of the TBL into company operations increases both long-term shareholder value and the transparency of business activities has gained favourable support (Cerin \& Dobers 2001; Lopez, Garcia \& Rodiguez 2007). Research concerning the BSC methodology has also been conducted with DJSI-listed firms. However, the adoption/integration of the BSC approach to sustainability development is still at "an embryonic stage” (Ricart et al. 2005, p26).

Westpac initiated its standalone sustainability reporting in 2002, and has subsequently maintained its pioneering position within the Australian banking sector. In comparison to other major banks in Australia, Westpac not only has the longest history of sustainability reporting, but also acts as a significant contributor to the development of sustainability reporting frameworks, in particular The Financial Services Sector Supplement (FSSS) issued by the Global Reporting Initiative (GRI) (GRI 2006a). The benefits of this unique position are twofold: on the one hand, Westpac uses its leadership role to advocate sustainability philosophies through its input to authoritative frameworks; while on the other hand, Westpac refines its own sustainability reporting by engaging in genuine key stakeholder dialogues; identifying potential gaps in the reporting framework for continuous improvement. This enables Westpac to play a key role in both the development and implementation of these frameworks.

The GRI's prescribed disclosure formats have been adopted by Westpac ever since its first standalone sustainability report in 2002. As suggested by Lamberton (2005), the GRI represents a rigorous framework for the application of TBL reporting. Therefore, companies that adopt the GRI as their sustainability disclosure framework often categorise sustainability performance indicators using a TBL approach. Westpac is no exception. However, the TBL approach does not clearly indicate the trade off between stakeholder expectations that the company encounters with TBL reporting (Robins 2006), nor does it reveal any cause and effect relationship(s) between the three pillars of the TBL (Hussey, Kirsop \& Meussen 2001). Hence, when using the TBL to communicate sustainability performance, it lacks clarity, with unclear causal relationships between sustainability performance and stakeholder groups (Robins 2006). Finally, Frost et al. (2008) question whether the ambiguous TBL reporting format embraced in GRI guidelines will in fact provide relevant information to potential stakeholders with various interests in firms' sustainability performance.

Therefore, this study attempts to translate the traditional TBL reporting that Westpac currently adopts into a set of BSC measurements. By doing so, the sustainability performance indicators that Westpac chooses to disclose are linked with certain stakeholders' expectations under the four perspectives of BSC. As a consequence, a clarified relation between sustainability reporting and stakeholder expectations can be established which enables a better assessment of organisational legitimacy as stakeholders' expectations are a key source of organisational legitimacy (Deegan 2007).

\section{Literature Review}

Sustainability Reporting

Buhr (2007) suggested that while social, environmental and sustainability reporting is linked with modern corporations, some elements of this reporting, such as employee and community issues, have been used by corporations for decades. For example, Guthrie and Parker (1989) conducted research on 100 years of BHP's annual reports (starting as early as 1885). 
Although limited focus was provided in these early annual reports, they are considered to be the first generation of sustainability reporting. In the 1990s, the emergence of environmental reporting replaced the trend towards social responsibility. Later, Elkington (1999) introduced the term "Triple Bottom Line" (TBL), which represented a system of reporting that linked environmental and social aspects with the economic performance of corporations.

There are now numerous widely-accepted reporting frameworks, such as the GRI Sustainability Reporting Guidelines (G3) (GRI 2006b). These guidelines aim to provide benefits for both reporting organisations and report users by promoting a standardised approach that potentially minimises ambiguity and rhetorical messages. As noted, Westpac is one of the Australian representatives in the international multi-stakeholder group of the GRI that developed the supplements for the financial service sector.

Even though the disclosure content and the length of sustainability reports have changed over time, their function has remained the same - to discharge accountability (Buhr 2007; Gray \& Bebbington 2000). Hence, research conducted on a firm's sustainability reporting will focus on the motivation and deemed purpose of the firm.

\section{Legitimacy Theory}

Social and environmental accounting (SEA) research has rapidly developed since the 1990s. In Thomson's (2007) summary of the sustainability accounting literature, frequently used theoretical frameworks include legitimacy theory, stakeholder theory and institutional theory. These theories are based on the assumption that an organisation lives within an "open system" containing great numbers of different entities that the firm may influence or be influenced by (Deegan 2002).

Legitimacy theory, one of the "most pervasive augmentation (SEA) theories" (Parker, 2005), asserts that in order to operate in a society, the firm's activities must be regarded as legitimate (Deegan 2002; Lindblom 1994). This theory does not recognise any particular stakeholder group of an organisation as being essential, but rather considers the entire system as a source of legitimacy (Deegan 2002). The majority of accounting studies applying legitimacy theory have been conducted in the manufacturing industry (Deegan 2002; Guthrie \& Parker 1989; Hogner 1982), with the most common approach being the matching of an organisation's social and environmental performance disclosures to negative social exposures. The mismatch between an organisation's value system and the societal value system is known as the legitimacy gap, while reporting sustainability performances can be viewed as strategies to gain, repair or maintain its legitimacy (Deegan 2007) as well as to reduce the legitimacy gap.

The development and implementation of legitimacy theory significantly advanced after the introduction of the TBL (Elkington 1999). Although this reporting initiative framework made the rather simplistic assumption that a common ground exists in corporate social and environmental disclosures in regard to industry identity or managerial style, it served as an indication of the growing awareness of the importance of those performance indicators, especially the non-financial indicators.

If a gap is perceived to exist it is essential for an organisation to craft and implement a variety of strategies, labelled as "legitimation tactics" (O’Donovan 2002, p. 349), to contribute to gaining, maintaining or repairing its legitimacy. Voluntary reporting on social and environmental issues as such a strategy from the perspective of legitimacy theory, has been the subject of earlier research. For example O'Donovan (2002) used a qualitative approach based on a questionnaire containing fictitious environmental issues to examine managers' intentions in relation to various legitimation tactics. Milne and Patten (2002) studied the environmental disclosures of the American chemical industry to determine 
whether positive environmental disclosures could repair organisational legitimacy. However, a question remains concerning the creditability of both the O'Donovan (2002) and Milne and Patten (2002) studies. O’Donovan examination of manager's intention of using legitimation tactics could not be verified as fictitious events were used in the study. In contrast the outcome of Milne and Patten's (2002) work, based on substantive incidents, concluded that while increasing the disclosure was driven by management's intention to repair legitimacy this finding was not robustly tested. By reviewing the results of both studies, it can be determined that a relationship does exist between organisations' perceived legitimacy gap and the implementation of legitimation tactics of voluntary social and environmental reporting.

\section{The Balanced Scorecard}

Developed by Kaplan and Norton (1992), the BSC is a structured tool to assist performance measurement and management, consisting of non-financial and financial objective measurements. It evaluates the expectations and demands of relevant stakeholders, and generates strategic possibilities to meet those demands (Bieker 2002). However, it provides neither a universal bottom-line target nor specified recommendations. The BSC's main purpose is to overcome the sole reliance on financial performance (Horngren et al. 2010). Hence, it provides a framework for performance setting in four categories, specifically: financial; customer; internal business processes; and learning and growth (see Figure 1 below).

Figure 1

The Balanced Scorecard

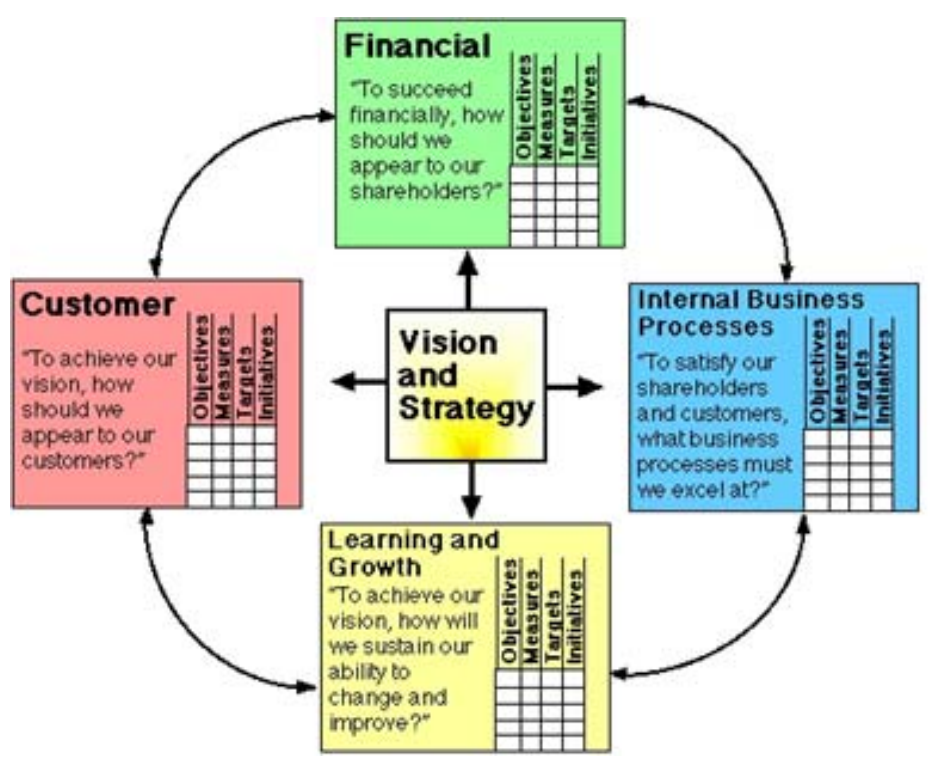

Adapted from Kaplan and Norton (1996, p76)

These perspectives represent the relevant stakeholders that Kaplan and Norton regarded as crucial to any type of organisation. The methodology itself evolves from a performance management tool into a strategic tool, as it is found that the BSC affects and benefits managers' decision making (Birch 2000; Lipe \& Salterio 2000). In order to use the BSC for strategic reflection and implementation, an organisation must ensure that its 
perspectives are consistent and align with the organisation's objectives and strategies (Chan 2004; Mooraj, Oyon \& Hostettler 1999).

Substantial research has been performed on the adoption and implementation of the BSC. Findings suggest that the core philosophy of the BSC centres on cause-and-effect relationships (Likierman 2006; Souissi \& Itoh 2006; Werner \& Xu 2012). Kaplan and Norton (1992) have defined such a relationship as a logical chain in the transformation of intangible assets into tangible value through the integrations of lead and lag indicators. Within different organisations and industrial sectors, these cause-and-effect relationships can become significantly complex, hence it is necessary that each organisation adopts a unique BSC and selects relevant measurements (Malmi 2001).

A significant limitation exists in early generations of the BSC, in that it fails to address the needs of all crucial stakeholders. Some of these exclusions include: effects on the environment; human resource (HR) issues; communities which the organisation operates within and supplier contributions (Smith 2005). Importantly, all exclusions have proved to be critical to a firm's survival and profitable development (Keating et al. 2008), highlighting the need to align these dimensions to organisations and the expectations of their stakeholders. This leads to the recent development of the SBSC.

\section{The Sustainability Balanced Scorecard}

As previously discussed, the original four perspectives do not encompass all stakeholder expectations. However, newer generations of the BSC still lack comprehensive measurements in the broader area of sustainability. There have been different approaches to integrate sustainability measurement into the traditional BSC approach. For example, in a 'modular' approach, sustainability can be added to the original four perspectives of the BSC as a standalone perspective; or the social and environmental aspects can be integrated into the original four perspectives (Figge et al. 2002). Bieker (2002) takes such an integrative approach. His SBSC is based on the traditional BSC's four categories, with the inclusion of an additional perspective (social or environmental) to address strategic orientation sustainable development. This research uses Bieker's method (2002). The rationale for this approach is that it is difficult to distinguish a set of measurements that solely evaluate social and environmental performance and that are not associated with the original four perspectives.

An impediment of the original BSC, as indicated by Cheney (2001), is the determination and quantification of non-financial performance indicators. The SBSC approach would experience increased difficulties as social impacts are even more difficult to measure and ultimately quantify. Therefore, many SBSC studies narrowly focus on sustainability indicators which are easily quantified. For example, Dias-Sadinha and Reijnders (2005) evaluate social and environmental performance in their study of 13 Portuguese firms. Their selection of firms focused on those industries that had a significant environmental impact, and the indicators used in their SBSC emphasised pollutionprevention and eco-efficiency. Similar applications of BSC (or SBSC) can be found in Moller and Schalteggar (2005) and Sidiropoulos et al. (2004), where an environmental perspective is added to the BSC. These applications are still not truly as comprehensive as a sustainability performance evaluation system needs to be, as eco-efficiency counts for only a narrow segment of broader sustainability issues. As suggested by Moller and Schalteggar (2005), a comprehensive SBSC should connect all the pillars of sustainability. 


\section{Research Design}

The sustainability reports of Westpac from 2002 to 2008 were analysed from two perspectives. Firstly, performance indicators were categorised into the four traditional BSC perspectives. The number of indicators used then quantified the reporting/disclosure in each category. The purpose of this measurement was to identify any changes in emphasis for each category of Westpac's sustainability reporting. Secondly, the disclosure by management of sensitive issues was analysed to identify legitimisation tactics from Westpac (identifying these disclosures as methods to gain, maintain or repair legitimacy). By summarising the legitimisation disclosures identified in each year's report, this research aims to evaluate Westpac's change in strategies used to fulfil organisational legitimacy.

In order to allocate the disclosures of the stakeholder impact indicators used in Westpac's reports into the perspectives of a BSC system, each perspective needs to be expanded to cover the domains of sustainability reporting. This re-classification of indicators allows those selected to be examined separately from a traditional TBL approach (which is suggested by the categories used in Westpac's report: social, environmental and economic). The rationale of this new method is that Westpac does not operate in an industry sector where environmental impact is the major sustainability concern, thus their reporting on environmental issues has a different focus compared to the heavy manufacturing industries.

Within the social regime of sustainability reporting, Westpac has an extremely high contact frequency with many different customers, and due to this close engagement the social impacts of any strategic decision are much more directly associated with the general public. Following the TBL, it is clear that Westpac emphasises social impact. However, its categorisation is ambiguous. In its 2002 report, Westpac categorised its policy for institutional banking as a social indictor and the total lending amount as an environmental indicator, causing inconsistency and ambiguity. The new SBSC approach attempts to clarify such ambiguity by re-allocating those indicators into Balance Scorecard perspectives, and, furthermore, to determine which perspective has attracted the strongest sustainability reporting. By doing so, it potentially allows the case study to translate Westpac's sustainability management strategy into a set of dashboard measurements. These are detailed below.

Figure 2

Illustration of Westpac's SBSC

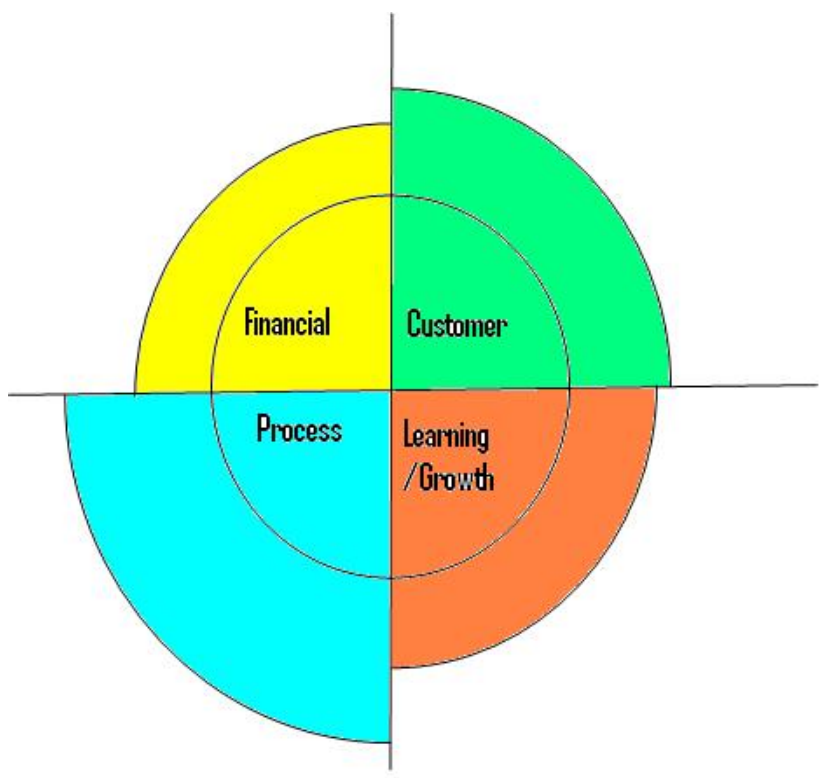


Figure 2 illustrates the proposed outcome from analysing the indicators that Westpac chooses to disclose in its sustainability reporting under the new SBSC categorisation.

Financial Perspectives: originally, the financial perspective evaluated the profitability of the strategy. Although there is no available accredited evidence that a direct relationship between sustainability management and financial profitability exists, results related to financial performance can still be observed in cost reduction, both direct (energy/material consumption) and indirect (compliance cost or penalties). The expanded financial perspective also includes the asset management and investments/contributions made in relation to sustainability management. In light of sustainability management, this perspective should not only include the sole purpose of enhancing tangible shareholder value.

Customer Perspective: identifies customer groups and segments and the firm's share of the market. It evaluates the firm's strengths and weaknesses in those segments. In this case study, it is expanded from a customer focus into the external supply chain, such as disclosures on logistics and the sustainability management practices of suppliers.

Internal Business Process Perspective: initially, this measures the effect of internal operations on value creation, such as innovation, services and efficiency. By expanding this measurement into sustainability indicators, it also includes the settlement and development of operational policies in both the traditional management and sustainability management regimes.

Learning and Growth Perspective: this relates to the capabilities that lead to superior process efficiency, most importantly the preservation and enhancement of both employees' capabilities and morale. The sustainability view is not very different from this as it includes disclosures of employee profiles, workloads, rewards and empowerments.

Table 1 below is an illustration of how sustainability indicators are 're-classified' using criteria of SBSC discussed above:

Table 1

Re-classification of Selected Indicators from Westpac's 2002 Sustainability Report
\begin{tabular}{|l|c|c|}
\hline \multicolumn{1}{|c|}{ Indicator } & $\begin{array}{c}\text { Original } \\
\text { (TBL) } \\
\text { Category }\end{array}$ & $\begin{array}{c}\text { SBSC } \\
\text { Perspective }\end{array}$ \\
\hline CSR Policy & Social & Internal Process \\
\hline Employee turnover \& job creation & Social & $\begin{array}{c}\text { Learning \& } \\
\text { Growth }\end{array}$ \\
\hline Lending profile (SME) & Social & Customer \\
\hline Environmental policy statement & Environmental & Internal Process \\
\hline Electricity Consumption & Environmental & Financial \\
\hline Policy Statement (SRI) & Environmental & Internal Process \\
\hline Profit earning & Economic & Financial \\
\hline Efficiency & Economic & Internal Process \\
\hline
\end{tabular}

Identifying Legitimisation Tactics

Traditionally applied in most research on the framework of legitimacy theory, entire sections of sustainability reporting were analysed in order to identify the legitimisation tactics used by management. These methods included matching negative media exposures to the growth of disclosure content in relation to such criticism. Since the source documents used in previous 
research are largely annual reports, identifying such a causal relationship requires more subjective interpretations on management's intentions.

However, in stand-alone sustainability reports such as Westpac's, the management of sensitive issues is deliberately reported and highlighted, hence indicating that is likely that the management of Westpac intentionally provides these disclosures for legitimisation purposes Although the 'sensitive issues' heading is categorised as an individual indicator under social performance in the indicator index, in actual fact it contains the disclosure of issues affecting many different stakeholders. Examining those issues considered by the Westpac management to be sensitive assists in understanding their sustainability management principles. Conducting a horizontal analysis also aids in identifying changes in the focus areas of those sensitive issues. The purposes of these tactics are to:

Gain Legitimacy: previous research has shown that Westpac's sustainability reporting began well before 2002. It did not start with pioneering and proactive motives but, instead, was a reactive response to the late 1990s legitimacy gap (Baxter et al. 2010). Therefore, in order to distinguish gaining legitimacy from maintaining legitimacy, this case study considers the publishing of a stakeholder impact report as a new starting point for Westpac's organisational legitimacy management. While preserving customers and market share and complying with regulations and standards will be considered as maintaining legitimacy, gaining legitimacy consists of developments and improvements, such as new frameworks, policies, initiative programs or projects.

Maintain Legitimacy: as previously mentioned, continuously preserving the efforts/contributions with no or little improvements towards sustainability management will be considered as a tactic to maintain legitimacy.

Repairing Legitimacy: disclosures made in response to criticisms and negative exposures will be categorised as tactics used to repair legitimacy. In these circumstances, a crisis of legitimacy is perceived to exist, with management deliberately implementing strategies to minimise the legitimacy gap.

The sensitive issues will be summarised, interpreted as one of the three tactics, and the target audience discussed to review and understand Westpac's approach in managing organisational legitimacy in relation to sustainability management.

\section{Results}

The first stand-alone Stakeholder Impact Report from Westpac in 2002 is used as an illustrative example, followed by the 2008 report and finally a comparative analysis from 2002-2008 is given. 2002 is recognised as the start of Westpac's sustainability strategy, or "Squashed Tomato Strategy" (Baxter et al. 2010). It received its name from the cover feature of a smashed tomato illustrating the fresh perspective of its stakeholder impact reporting.

Applying the SBSC approach, discussed previously, to the list of indicators used in the 2002 Social Impact Report, it was observed that out of the 65 indicators, 23 of them can be categorised into the customer (or external) perspective, 18 into the financial perspective, 14 into the internal process perspective and 10 into the learning and growth perspective. These are illustrated in Figure 3. 
Figure 2

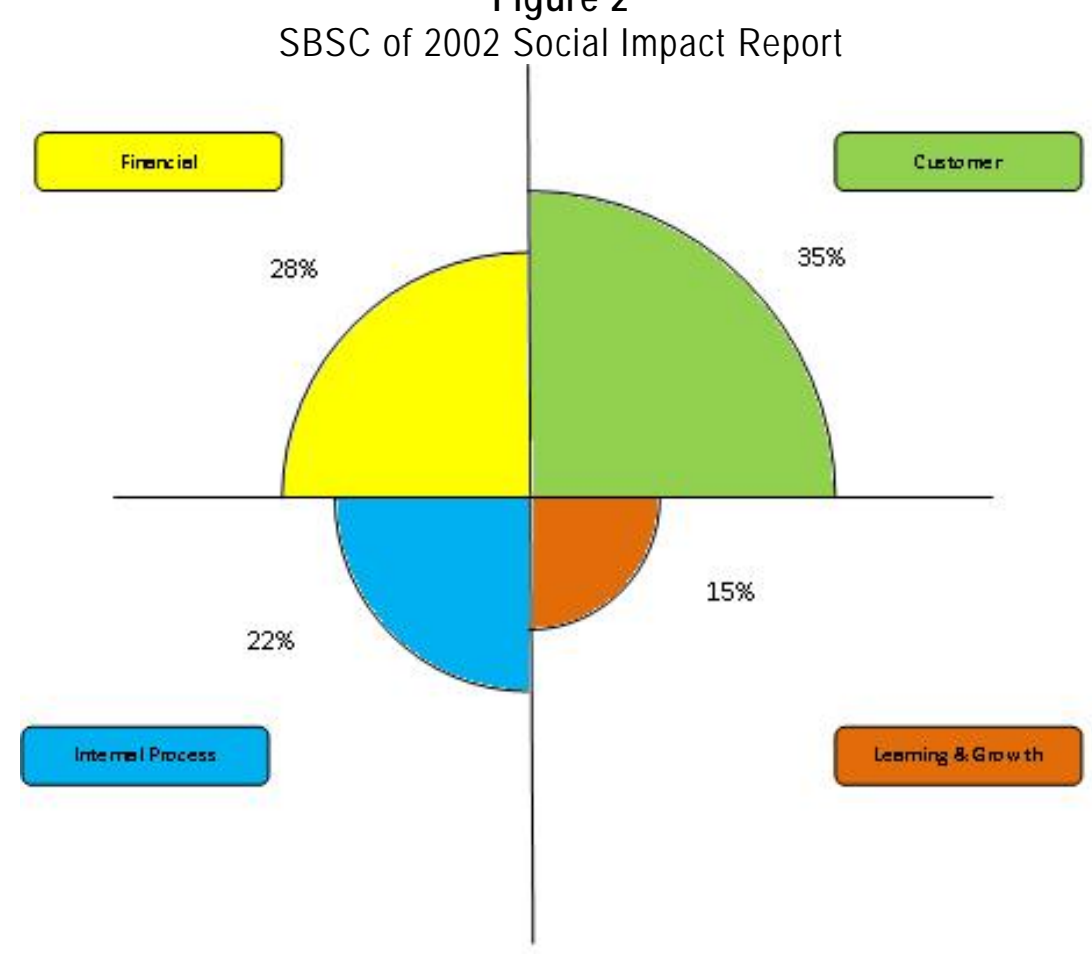

In the 2002 Social Impact Report (Westpac 2002), the management of Westpac made disclosures relating to five issues which they believed sensitive: Dealing with the Government; Political Donations; Responsible Lending Banking Business; Indigenous Partnership; and Financial Auditor Independence. Table 2 below summarises the disclosure Westpac provided regarding these sensitive issues and their potential legitimisation effects. From Table 2 it can be observed that Westpac's management adopted various legitimisation tactics in the 2002 sustainability report's coverage of sensitive issues. Lindblom's (1994) prescription of legitimisation tactics and purposes can be observed from the results above. For instance, Westpac displayed its conformation of expectations in relation to risk mitigation policies to maintain legitimacy. In addition, it also provided defensive disclosures towards criticisms in order to repair its legitimacy gap and promoted its support of the Indigenous community to gain legitimacy due to potential social value change. 
Table 2

Sensitive Issues Disclosed in Westpac's 2002 Sustainability Report

\begin{tabular}{|c|c|c|c|}
\hline Heading Used & Issues & $\begin{array}{c}\text { Main } \\
\text { Target } \\
\text { Audience } \\
\end{array}$ & $\begin{array}{l}\text { Legitimisation } \\
\text { Purpose }\end{array}$ \\
\hline \multirow[t]{2}{*}{$\begin{array}{l}\text { 1. Dealing with the Government \& } \\
\text { Political Donations }\end{array}$} & $\begin{array}{l}\text { 1.1 Contribute to } \\
\text { public policy } \\
\text { development }\end{array}$ & Government & Gain \\
\hline & $\begin{array}{l}1.2 \text { Donations } \\
\text { Purpose }\end{array}$ & Public & Gain/Repair \\
\hline \multirow[t]{5}{*}{ 2. Responsible Lending } & $\begin{array}{l}\text { 2.1 Risk } \\
\text { Management } \\
\text { Principles } \\
\end{array}$ & Shareholder & Maintain \\
\hline & 2.2 Credit Criteria & Shareholder & Maintain \\
\hline & 2.3 Accessibility & Customer & Maintain \\
\hline & $\begin{array}{l}\text { 2.4 Lending to High } \\
\text { Social Benefit }\end{array}$ & Community & Gain \\
\hline & $\begin{array}{l}\text { 2.5 Community } \\
\text { Banking in Rural } \\
\text { Areas }\end{array}$ & Community & Maintain \\
\hline \multirow[t]{3}{*}{ 3. Banking Business } & $\begin{array}{l}\text { 3.1 Anti Money } \\
\text { Laundering }\end{array}$ & $\begin{array}{l}\text { Government } \\
\text { /Public }\end{array}$ & Maintain \\
\hline & $\begin{array}{l}3.2 \text { Termination of } \\
\text { Mortgage \& Income } \\
\text { Fund }\end{array}$ & Public & Repair^ \\
\hline & $\begin{array}{l}\text { 3.3 Reform Credit } \\
\text { Card Scheme }\end{array}$ & Government & Maintain \\
\hline \multirow[t]{2}{*}{ 4. Indigenous Partnership } & $\begin{array}{l}\text { 4.1 Cape York } \\
\text { Program }\end{array}$ & Community & Gain \\
\hline & $\begin{array}{l}\text { 4.2 Balknu Cape } \\
\text { Development }\end{array}$ & Community & Gain \\
\hline 5. Financial Auditor Independence & $\begin{array}{l}5.1 \text { Auditor } \\
\text { Independence }\end{array}$ & Shareholder & Maintain \\
\hline
\end{tabular}

Note $^{\wedge}$ : the termination of the Mortgage and Income Fund on 22 June 2001 resulted in an ASIC investigation. Westpac announced that the company has implemented a new review mechanism to prevent similar incidents.

In 2008, Westpac experienced a major change in its management. Westpac's CEO, David Morgan, left the organisation. The Stakeholder Impact Report (Westpac 2008) was also changed in that year. The volume of the printed report was significantly reduced as more information was made available online at Westpac's corporate social responsibility website. Some new indicators were included in the sustainability report in addition to those previously used, which contained unexpected and interesting information. For example under the disclosure for social performance, using suppliers with a Fair Trading policy was introduced as part of Westpac's Sustainable Supply Chain Management (SSCM) strategy. The example given is that Westpac started to provide coffee from Fair Trading suppliers (also paper coffee cups) to more than 8,000 employees through company cafeterias. The company believes that this is an effective strategy to communicate the company values of incorporating sustainability principles into its day-to-day company business (in this case, purchasing decisions).

When applying the SBSC approach on the total of 88 indicators used in Westpac's 2008 sustainability report, results indicate that 36 indicators belong to the customer 
perspective, 24 to the financial perspective, while the internal business process perspective and learning and growth perspective have 7 and 9 indicators respectively, as illustrated below in Figure 4:

\section{Figure 4}

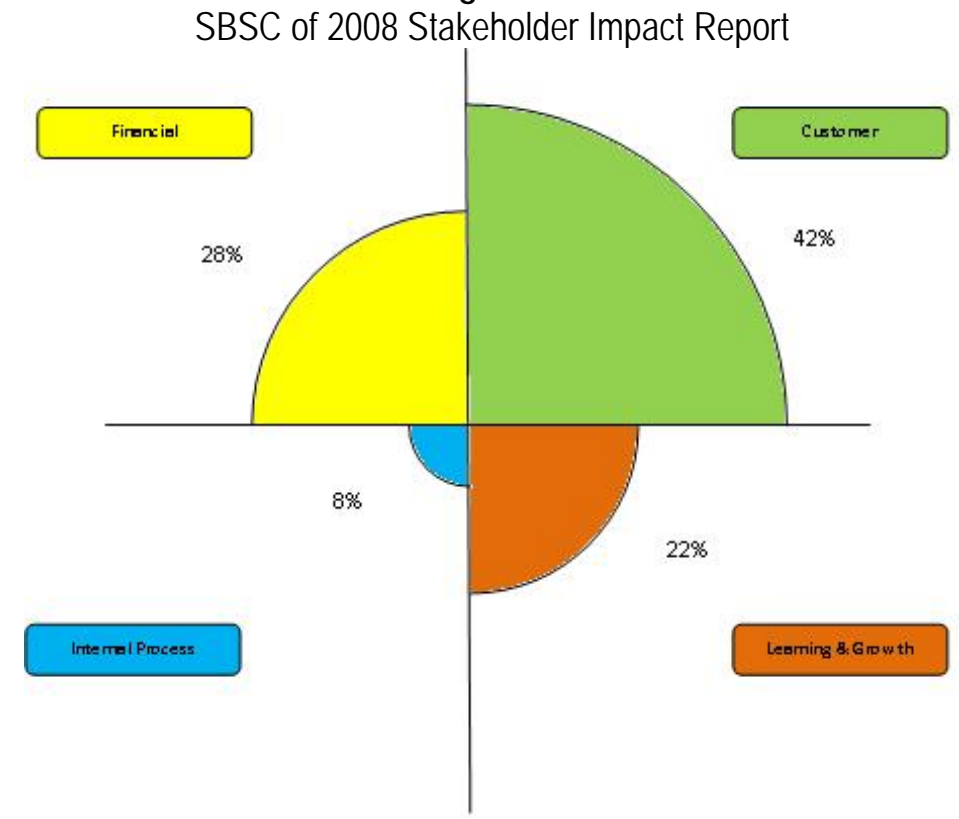

Besides the existing issues, in 2008 more employee-related matters were reported, which provided the same outcome as the BSC approach, where higher learning and growth perspective indicators were observed. Two of the most significant issues were the Global Financial Crisis and the departure of the former CEO. These events had little impact on the content and format of Westpac's sustainability reporting, perhaps due to the fact that this established reporting framework has been underpinned into the sustainability management of Westpac.

The disclosure of sensitive issues in Westpac's 2008 sustainability report was double that revealed in 2002. This is illustrated in Table 3.

Clearly, the Global Financial Crisis (GFC) has influenced Westpac's legitimacy status significantly. The management considers that protecting the general public from the GFC is a priority for Westpac's organisational legitimacy. Besides the repeated issues including responsible lending and risk management, disclosure of new sensitive issues such as climate change, employee development and social entrepreneurship have become Westpac's new source of legitimacy. This indicates that these issues are currently seen as important for business' sustainability management, due to their gaining higher social awareness. 
Table 3

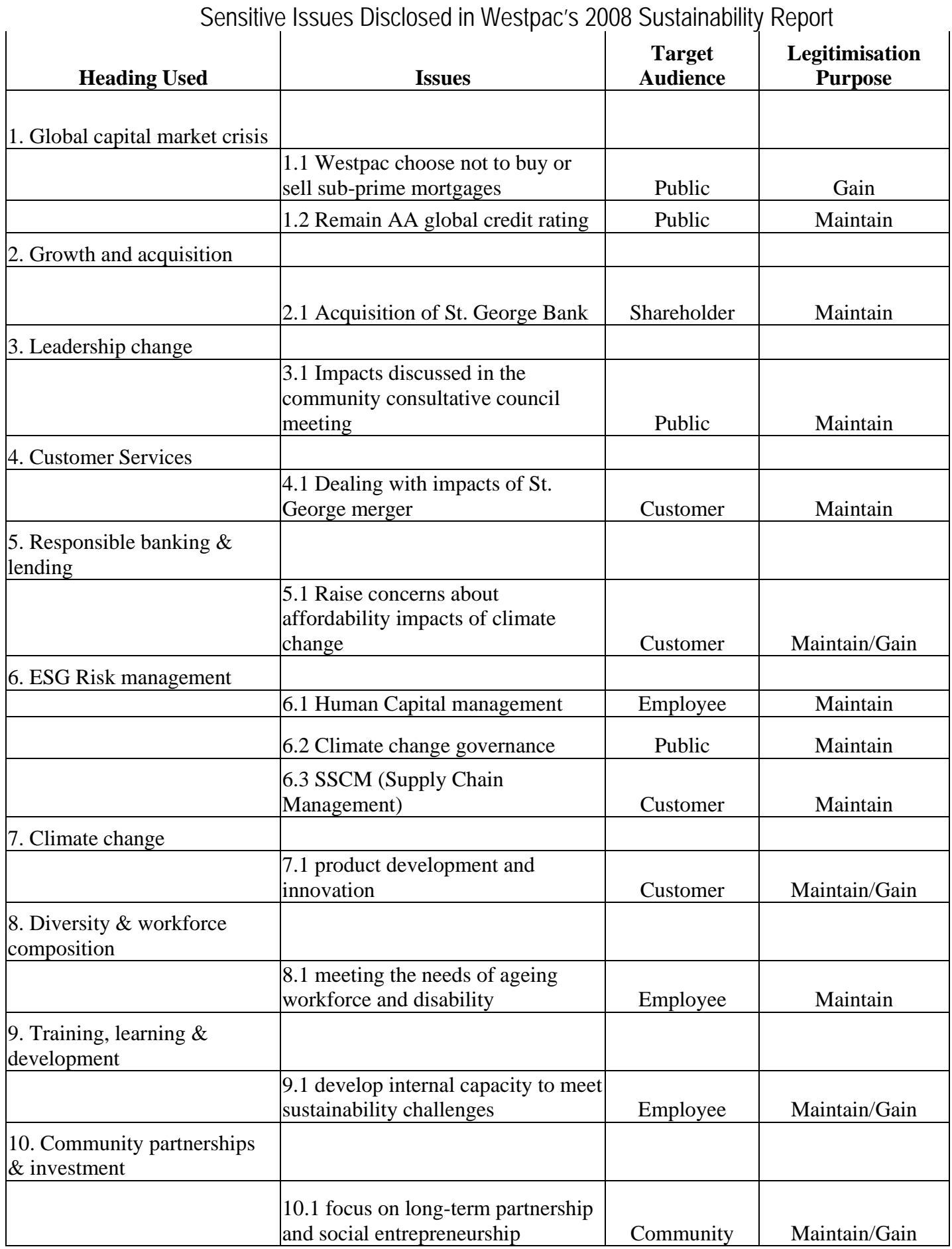

\section{Comparison of Results}

Based on the individual results of each annual sustainability report, a summary and comparison were made to identify patterns in changes or innovations. It is clear that there are 
two distinctive stages, the 2002-2004 Social Impact Reports and the 2005-2008 Stakeholder Impact Reports period.

The first period's reports used a TBL structured reporting format, where indicators are categorised as social, environmental or economical. It can be seen as the early developmental stage of Westpac's sustainability management and reporting, where the establishment, implementation and change of various policies reflecting sustainability concerns became the essential information disclosed in the report. This, in turn, was reflected by the increasing percentage of the internal business process perspective under the BSC approach. From the legitimacy perspective, active participation in policy development is viewed as an effective legitimacy-gaining tactic; by showcasing advocacy in these sensitive matters Westpac demonstrates its commitment and leading position in sustainability management.

In the next period a change in the reporting pattern was identified, where much less reporting on policies was used as an indicator. Instead, structured themes were introduced in every section of sustainability reporting to communicate management's philosophy and corporate value in relation to sustainability matters. The categorisation has evolved from the traditional TBL to the six new classifications, where the customer, employee and supplier category are separated from the former social category for an extended view on corporate social responsibility. The indicators reported under the customer and financial perspectives significantly increased during this period, indicating the dominating factor - Westpac's service-profit model.

\section{Comparative Table}

Figure 3

SBSC Comparative Table 2002-2008

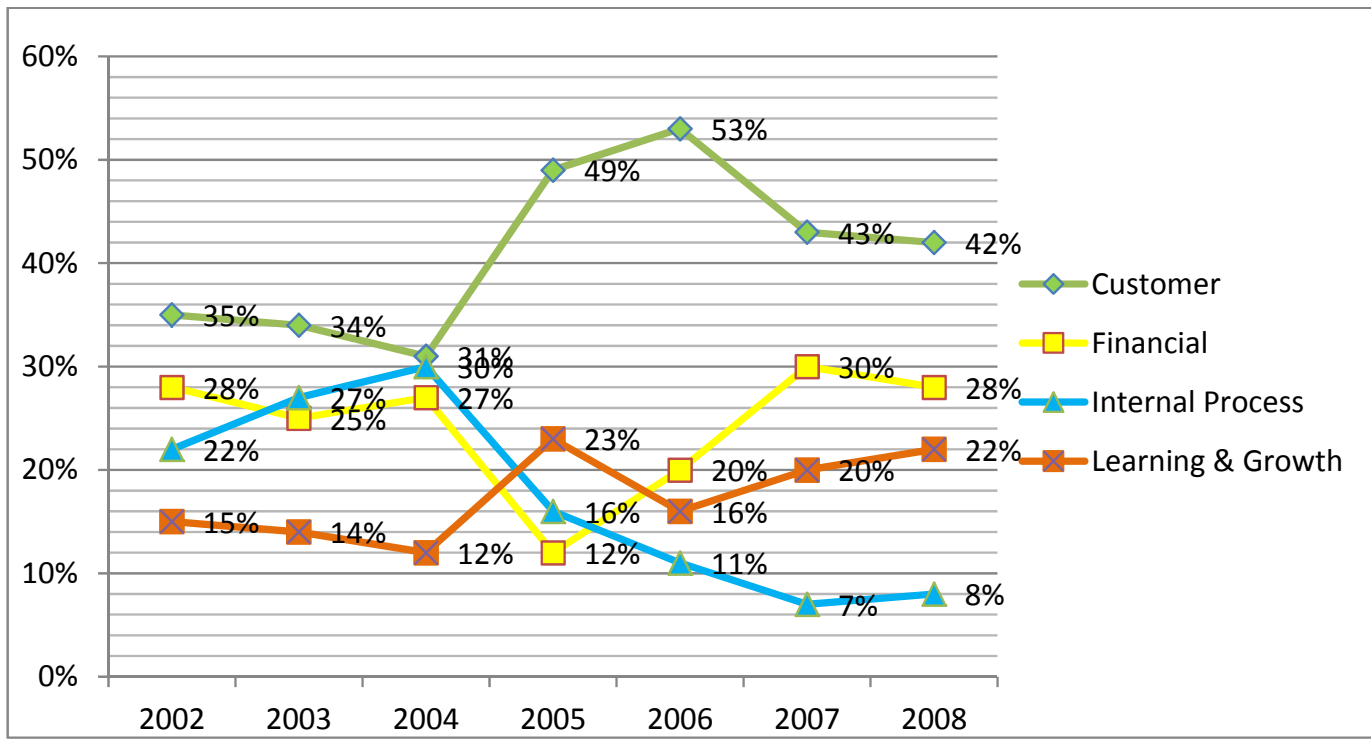

Figure 5 above illustrates the change of disclosure strength among each of the SBSC perspectives for the period $2002-2008$.

The disclosure of customer related indicators remains steadily above the other perspectives, due to the dominant service to profit model that Westpac management promotes and the establishment of SSCM procedures. The firm has paid a lot of attention to its consumer groups, and implemented a series of sustainability-related supply chain 
management strategies. This result is expected because of the nature of Westpac as a servicefocused firm.

The disclosure of financial performance is also relatively consistent, despite the sharp decline in the 2005 report. A possible explanation for this decline could be that 2005 was the first year that Westpac synchronised the annual and sustainability reports. Since the annual report disclosed all of the detailed financial performance indicators, it is possible that the firm did not consider it necessary to disclose them again in the sustainability report. However, in the following years the financial disclosure returned to its former significance, which demonstrates that even though the sustainability reports are targeted towards noncore financial stakeholders, financial performance remains an important part of sustainability performance.

The disclosure in the internal business process perspective grew in the first period of significance (2002-2004, or the 'social impact report' period), and then began, and continued, to decline in the second period of significance (2005-2008, or the 'stakeholder impact report' period). Since the policy development and procedure-setting related disclosures are categorised in this perspective, it indicates that Westpac developed and implemented more sustainability-related policies in the first three years. They then matured into systematic policies and procedures which became part of the corporate culture, and hence fewer disclosures were required in the following years.

Table 4

Westpac's Community Consultative Council in 2005

\begin{tabular}{|l|l|l|}
\hline Organisations & Type & Interests \\
\hline Australian Council of Trade Unions & Workers Union & Employee Rights \\
\hline Australian Conservation Foundation & NFP & Environment \\
\hline Australian Consumers' Association & NFP & Consumer Rights \\
\hline Australian Council of Social Service & Community Service & Poverty \& Inequality \\
\hline City of Melbourne & Governmental & Vary \\
\hline Commonwealth Department of Family and Community Services & Governmental & Social Benefits \\
\hline Commonwealth Department of the Environment and Heritage & Governmental & Environment \\
\hline Environmental Protection Authority Victoria & Authority & Environment \\
\hline Finance Sector Union & Workers Union & Employee Rights \\
\hline Human Rights and Equal Opportunity Commission & Statutory Organization & Human Rights \\
\hline Landcare Australia & Governmental & Environment \\
\hline Mission Australia & Community Service & Social Benefits \\
\hline National Seniors Association & NFP & Social Benefits for 50+ \\
\hline NSW Department of Planning & Governmental & Environment \\
\hline Our Community & Community Service & Community Network \\
\hline Reconciliation Australia & NFP & Indigenous \\
\hline St James Ethics Centre & NFP & Promotion of Ethics \\
\hline The Salvation Army & Community Service & Social Benefit \\
\hline The Smith Family & Charity & Disadvantaged Children \\
\hline University of Technology Sydney & Education & Education/Careers \\
\hline WWF Australia & NFP & Environment \\
\hline & & \\
\hline
\end{tabular}

In contrast, the disclosure of the learning and growth perspective declined in the first period, and then increased and remained steady in the second period. From the analysis of the 
indicators, it appears that the measurement within this perspective remained conventional, as the indicators were used repetitively across all years, and there was very little innovation observed. This reveals an issue in measuring sustainability performance, as it is difficult to quantify and capture the learning and growth perspectives, despite this being very important to the firm's sustainability.

It is clear that Westpac addresses sensitive issues related to expectations of a broad set of stakeholder groups. One of the main strategies that Westpac adopted to make its legitimisation tactics inclusive was establishing a stakeholder dialogue mechanism Community Consultative Council (CCC) made up of more than 20 groups representing various interests and expectations. This is illustrated in Table 4.

A potential benefit of establishing a stakeholder dialogue mechanism, such as the CCC, is that it provides a source of consulting information to assist Westpac's management in assessing relevant issues contributing to organisational legitimacy. Also, according to Bebbington, Unerman and O’Dwyer (2007), a meaningful stakeholder mechanism is crucial for reporting sustainability and discharging accountability.

\section{Conclusions}

The previous section presented the findings of the analysis of Westpac's sustainability performance reports using the SBSC approach and reviewed through the lens of legitimacy theory.

The results demonstrate that the contents of the reports are imbalanced when using the percentage of indicators under each perspective of the total indicator. Instead, results indicated that the firm emphasised the performances of indicators within the customer and financial perspectives. For reports in the first period (2002-2004), the combined customer and financial indicators contributed to more than $55 \%$ of the total indicators. This pattern became more significant in the second period, where, in 2005-2008, the figure exceeded $70 \%$.

There are a number of factors potentially contributing to this outcome. The first is that the financial service industry in which Westpac operates involves customer relationship management and financial performance measurement. Many of the indicators under the customer's perspective are service quality measurements, such as complaints and resolution rates. The service quality measures are essential elements of a service firm's operational objectives and it remains a key focus of Westpac's sustainability management. The serviceprofit model, emphasised in the sustainability reports since 2005, is also a dominating factor of continued increasing disclosure on customer-related and financial performances. The model itself promotes the importance of an employee's performance, motivation and involvement level; however, there are few innovations identified in Westpac's reporting on employee-related issues. The indicators used to represent the employee category did not undergo any major updates or shifts, although the other non-financial perspectives did. The majority of employee-related indicators were adopted from the G3 and FSSS, with the addition of Westpac's unique selection of indicators raised from the CCC and Internal committees' meetings.

The analytical results from the potential legitimisation tactics identified in Westpac's sustainability reports, clearly indicate that the company has and continues to respond to the expectations of stakeholders. From the view of the legitimacy theoretical framework, this study concludes that Westpac's sustainability reports contain a number of legitimisation tactics. For example to maintain legitimacy tactics include compliance with established frameworks, regulations and guidelines, anticipating stakeholder needs and attempting to provide products and services exceeding those needs. To repair legitimacy tactics include indicating avoidance or disclosing remedy procedures and prevention strategies. Finally to 
gain legitimacy tactics include participating with renowned associations, establishing and maintaining ongoing community partnerships, and showcasing advocacy by being actively involved in policy development for both government and sustainability associations.

The main organisational strategy to manage legitimacy-related sensitive issues is the stakeholder dialogue mechanism. Stakeholder engagement is a strategy recognised by the GRI and the Institute of Social and Ethical Accountability's Foundation Standard, AA1000 as a necessity to achieve meaningful sustainability reporting (Owen, Swift \& Hunt 2001), but little genuine stakeholder engagement has been identified in the domain of sustainability management (Cooper \& Owen 2007). Westpac's stakeholder dialogue can be considered as a rare example of effective stakeholder management. Since it originated in 2002, it has remained as a prioritised, constant feature of Westpac's sustainability reporting, as well as the essential output source for identifying legitimacy-threatening issues. Hence, it is recommended that firms could consider using the stakeholder dialogue mechanism as a strategy to develop context specific sustainability reporting.

Finally this paper addresses how using a BSC re-classification of sustainability indicators helps the understanding of how sustainability reporting contributes to maintaining organisational legitimacy. The traditional approach of legitimacy theory studies focus on identifying the cause-effect relationship between negative exposures and the legitimisation tactics embedded in corporate disclosures. However, the TBL approach of sustainability reporting does not reveal any certain cause-effect relationship between social, economical and environmental performances. In contrast, the BSC embraces the core philosophy of cause-effect relationships, while also addressing the key performances stakeholders are interested in (Kaplan \& Norton 2001). By translating Westpac's sustainability reporting into a set of measurements based on the SBSC model, the linkage between performance indicators and stakeholder expectations can be reviewed in a clearer manner. Together with the continuous effort of maintaining a genuine stakeholder dialogue mechanism, Westpac's sustainability reporting practices assist the company in better maintaining its key survival resource - organisational legitimacy.

\section{References}

Adams, C \& Narayanan, V 2007, 'Standardizing sustainability reporting', in J Unerman, J Bebbington, \& B O’Dwyer (eds), Sustainability Accounting and Accountability, Routledge, London, pp70-86.

Artiach, T, Lee, D, Nelson, D \& Walker, J 2010, 'The determinants of corporate sustainability performance’, Accounting \& Finance, vol.50, no.1, pp31-51. http://dx.doi.org/10.1111/j.1467-629X.2009.00315.x

Baskin, J 2006, 'Corporate responsibility in emerging markets', Journal of Corporate Citizenship, vol.24, pp29-47. http://dx.doi.org/10.9774/GLEAF.4700.2006.wi.00006

Baxter, J, Chua, WF \& Strong, P 2010, 'Westpac's squashed tomato strategy', Chartered Institute of Management Accountants, accessed 19/3/ 2011, http://issuu.com/cimaglobal/docs/westpac_squashed_tomato_march31/1?e=1740886/ 5093638

Bebbington, J, Unerman, J \& O'Dwyer, B 2007, 'Stakeholder engagement and dialogue'. Sustainability accounting and accountability, Routledge, London, pp1-17.

Bieker, T 2002, 'Sustainability Management with the Balanced Scorecard', in S Karner, I Oehme \& U Seebacher (eds), Corporate Sustainability, 5th International Summer Academy on Technology Studies, Deutschlandsberg, Austria, July 13-19, 2003, Conference Proceedings, pp17-34.

Birch, C 2000, Future Success, Prentice Hall, Melbourne, Australia. 
Buhr, N 2007, 'Histories of and rationales for sustainability reporting', in J Unerman, J Bebbington, \& B O’Dwyer (eds.), Sustainability accounting and accountability, Routledge, London, pp57-70. http://dx.doi.org/10.4324/NOE0415384889.pt2

Cerin, P \& Dobers, P 2001, 'What does the performance of the Dow Jones Sustainability Group Index tell us?', Eco-Management and Auditing, vol.8, pp123-133. http://dx.doi.org/10.1002/ema.159

Chan, YCL 2004, 'Performance measurement and adoption of balanced scorecards: A survey of municipal governments in the USA and Canada', International Journal of Public Sector Management, vol. 17, issue 3, pp204. http://dx.doi.org/10.1108/09513550410530144

Cheney, G 2001, 'AICPA survey finds performance measurement often ineffective', Accounting Today, vol.14, pp17.

Cooper, SM \& Owen, DL 2007, 'Corporate social reporting and stakeholder accountability: The missing link', Accounting, Organizations and Society, vol.32, no.7, pp649-667. http://dx.doi.org/10.1016/j.aos.2007.02.001

Deegan, C 2002, 'The legitimizing effect of social and environmental disclosures: A theoretical foundation', Accounting, Auditing and Accountability Journal, vol.15, no.3, pp282-311. http://dx.doi.org/10.1108/09513570210435852

Deegan, C 2007, Financial Accounting Theory ( $3^{\text {rd }}$ Edition), McGraw-Hill, Sydney

Dias-Sardinha, I \& Reijnders, L 2005, 'Evaluating environmental and social performance of large Portuguese companies: a balanced scorecard approach', Business Strategy and the Environment, vol.14, issue.2, pp73-91. http://dx.doi.org/10.1002/bse.421

Do, H, Tilt, CA \& Tilling, MV 2007, 'Corporate Social Disclosure by Westpac Banking Corporations: A study of social impact reports (2002-2004)', Business Conference Paper, Paper 6, accessed 7/9/ 2010 http://researchonline.nd.edu.au/bus_conference/6

Elkington, J 1999, Cannibals with forks. Capstone Punlishing, Mankato, MN, USA

Figge, F, Hahn, T, Schaltegger, S \& Wagner, M 2002, 'The sustainability balanced scorecard - linking sustainability management to business strategy', Business Strategy and the Environment, vol.11, issue.5, pp269-284. http://dx.doi.org/10.1002/bse.339

Frost, G, Jones, S, Loftus, J \& Van der Laan, S 2008, 'A Survey of Sustainability Reporting Practices of Australian Reporting Entities', Australian Accounting Review, vol.15, no.35, pp89-96. http://dx.doi.org/10.1111/j.1835-2561.2005.tb00256.x

Global Reporting Initiative, 2006a, Financial Services Sector Supplement, accessed 23/4/2010, https://www.globalreporting.org/resourcelibrary/FSSS-Complete.pdf

Global Reporting Initiative, 2006b, Sustainability Reporting Guidelines (G3), accessed 23/4/ 2010, https://www.globalreporting.org/resourcelibrary/G3-Guidelines-Incl-TechnicalProtocol.pdf

Gray, R \& Bebbington, J 2000, 'Environmental accounting, managerialism and sustainability: Is the planet safe in the hands of business and accounting?' Advances in Environmental Accounting \& Management, vol.1, pp1-44.

Guthrie, J \& Parker, L 1989, 'Corporate social reporting: A rebuttal of legitimacy theory', Accounting and Business Research, vol.19, no.76, pp343-352. http://dx.doi.org/10.1080/00014788.1989.9728863

Hogner, RH 1982, 'Corporate social reporting: eight decades of development at US Steel', Research in Corporate Social Performance and Policy, vol.6, pp243-250.

Hope, C \& Fowler, SJ 2007, 'A Critical Review of Sustainable Business Indices and Their Impact', Journal of Business Ethics, vol.76, pp243-252. http://dx.doi.org/10.1007/s10551-007-9590-2

Hopwood, AG 2009, 'Accounting and the Environment', Accounting, Organizations and Society, vol. 34, pp433-439. http://dx.doi.org/10.1016/j.aos.2009.03.002 
Horngren, CT, Forster, G, Rajan, M, Ittner, C \& Datar, SM (eds), 2010, Cost Accounting: $a$ managerial emphasis, American Accounting Association.

Hussey, DM, Kirsop, P \& Meussen, RE 2001, 'Global reporting initiative guidelines: An evaluation of sustainable development metrics for industry', Environmental Quality Management, vol.11, no.1, pp1-20. http://dx.doi.org/10.1002/tqem.1200

Kaplan, RS \& Norton, DP 1992, 'The Balanced Scorecard - Measures that drive performance', Harvard Business Review, Issue Jan-Feb, no.92105.

Kaplan, RS \& Norton, DP 1996,'Using the balanced scorecard as a strategic management system’, Harvard Business Review (January-February), p76

Kaplan, RS \& Norton, DP 2001, 'Transforming the balanced scorecard from performance measurement to strategic management: Part I’, Accounting horizons, vol.15, no.1, pp87-104.

Keating, B, Quazi, A, Kriz, A, \& Coltman, T 2008, 'In pursuit of a sustainable supply chain: insights from Westpac Banking Corporation', Supply Chain Management-An International Journal, vol. 13, no. 3, pp175-179.

Knoepfel, I 'Dow Jones sustainability group index: A global benchmark for corporate sustainability', corporate environmental strategy, vol. 8, no. 1, pp6- 15.

Lamberton, G 2005, 'Sustainability accounting - a brief history and conceptual framework', Accounting Forum, vol. 29, no.1, pp7-26. http://dx.doi.org/10.1016/j.accfor.2004.11.001

Likierman, A 2006, 'Technical Matters: The Balanced Scorecard', Financial Management, Nov Issue, p.9.

Lindblom, CK 1994, 'The implications of organizational legitimacy for corporate social performance and disclosure', paper presented at the Critical Perspective on Accounting Conference, New York.

Lipe, MG \&Salterio, SE 2000, 'The balanced scorecard; Judgmental effects of common and unique performance measures', The Accounting Review, vol.3, pp283-298.

Lopez, MV, Garcia, A\& Rodriguez, L 2007, 'Sustainable development and corporate performance: A study based on the Dow Jones Sustainability Index', Journal of Business Ethics, vol.75, pp285-300. http://dx.doi.org/10.1007/s10551-006-9253-8

Malmi, T 2001, 'Balanced scorecards in Finnish companies: A research note', Management Accounting Research, vol.12, no.2, pp207-220. http://dx.doi.org/10.1006/mare.2000.0154

Milne, MJ \&Patten, DM 2002, 'Securing organizational legitimacy: an experimental decision case examining the impact of environmental disclosures', Accounting, Auditing \& Accountability Journal, vol.15, no.3, pp372-405. http://dx.doi.org/10.1108/09513570210435889

Moller, A \& Schaltegger, S 2005, 'The sustainability balanced scorecard as a framework for eco-efficiency analyses, Journal of Industrial Ecology, vol.9, issue.4, pp73-83. http://dx.doi.org/10.1162/108819805775247927

Mooraj, S, Oyon, D \& Hostettler, D 1999, 'The balanced scorecard: A necessary good or an unnecessary evil?’, European Management Journal, vol.17, Issue 5, pp481-491. http://dx.doi.org/10.1016/S0263-2373(99)00034-1

O’Donovan, G 2002, 'Environmental disclosures in the annual report: extending the applicability and predictive power of legitimacy theory', Accounting, Auditing \& Accountability Journal, vol.15, no.3, pp344-371. http://dx.doi.org/10.1108/09513570210435870 
Owen, DL, Swift, T\& Hunt, K 2001, 'Questioning the role of stakeholder engagement in social and ethical accounting, auditing and reporting', Accounting Forum, vol. 25, no. 3, pp264-282. http://dx.doi.org/10.1111/1467-6303.00066

Parker, D 2005, 'Social and environmental accountability research: A view from the commentary box', Accounting, Auditing \& Accountability Journal, vol.18, no.6, pp842-860. http://dx.doi.org/10.1108/09513570510627739

Ricart, JE, Rodríguez, MÁ \& Sánchez, P 2005, 'Sustainability in the boardroom: An empirical examination of Dow Jones Sustainability World Index leaders', Corporate Governance, vol.5, no.3, pp24-41. http://dx.doi.org/10.1108/14720700510604670

Robins, F 2006, 'The Challenge of TBL: a responsibility to whom?', Business and Society Review, vol.111, no.1, pp1-14. http://dx.doi.org/10.1111/j.1467-8594.2006.00258.x

Schaltegger, S \& Wagner, M (eds), 2006, Managing the Business Case for Sustainability, Greenleaf Publishing, Sheffield, UK

Sidiropoulos, M, Mouzakitis, Y, Adamides, E \& Goutsos, S 2004, ‘Applying sustainable indicators to corporate strategy: The eco-balanced scorecard', Environmental Research, Engineering and Management, vol.1, no.27, pp28-33.

Smith, M 2005, 'The balanced scorecard', Financial Management, Feburary, pp27-28.

Souissi, M \& Itoh, K 2006, 'Implementing the Balanced Scorecard', Journal of Corporate Accounting and Finance, vol.17, Issue3, pp57-61. http://dx.doi.org/10.1002/jcaf.20198

Thomson, I 2007, 'Mapping the terrain of sustainability accounting', in J Unerman, J Bebbington, \& B O’Dwyer (eds.), Sustainability accounting and accountability, Routledge, London. http://dx.doi.org/10.4324/NOE0415384889.pt1

Unerman, J, Bebbington, J \& O’Dwyer, B 2007, 'Introduction to sustainability accounting and accountability’, in J Unerman, J Bebbington, \& B O’Dwyer (eds.), Sustainability accounting and accountability, Routledge, London.

Werner, ML \& Xu, F 2012, 'Executing strategy with the Balanced Scorecard', International Journal of Financial Research, vol.3, no.1, pp88-94.

Westpac (nd) Australia’s First Bank, accessed 24/4/2010, http://www.westpac.com.au/

Westpac, 2002, Social Impact Report, Melbourne.

Westpac, 2008, Stakeholder Impact Report, Melbourne. 